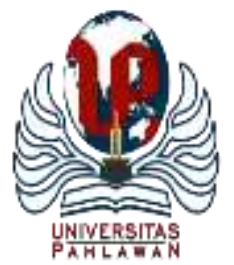

Edukatif : Jurnal Ilmu Pendidikan Volume 3 Nomor 6 Tahun 2021 Halm 3816 - 3827

EDUKATIF: JURNAL ILMU PENDIDIKAN

Research \& Learning in Education

https://edukatif.org/index.php/edukatif/index

\title{
Analisis Pemerolehan Bahasa pada Anak Usia 2,8 Tahun berdasarkan Mean Length of Utterance dalam Aspek Fonologi Morfologi dan Sintaksis
}

\author{
Hana Septiana Jamal ${ }^{1 凶}$, Hendra Setiawan ${ }^{2}$ \\ Universitas Singaperbangsa Karawang, Indonesia ${ }^{1,2}$

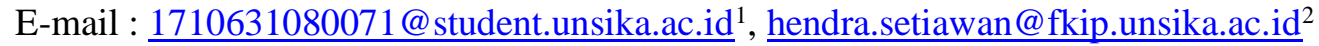

\begin{abstract}
Abstrak
Penelitian yang berjudul "Analisis Pemerolehan Bahasa pada Anak Usia 2,8 Tahun Berdasarkan Mean Length of Utterance dalam Aspek Fonologi Morfologi dan Sintaksis" bertujuan untuk mendeskripsikan rerata panjang tuturan anak pada usia 2 tahun 8 bulan, dan mengetahui apakah ada permasalahan dalam proses pemerolehan bahasa pada anak yang menjadi subjek penelitian. Adapun metode yang digunakan yaitu metode analisis deskriptif dengan pendekatan kualitatuif. Hasil penelitian ini dapat dilihat bahwa berdasarkan perhitungan MLU, kemampuan berbahasa yang dimiliki anak bernama Septi Asrilia Rahayu cukup tinggi, jauh di atas tingkatan yang seharusnya. Begitupun dengan aspek fonologi, morfologi, dan sisntaksisnya, bisa dikatakan sudah sangat baik. Dan dengan dilakukannya penelitian ini, dapat diketahui bahwa MLU merupakan metode pengukuran yang tepat untuk mengetahui seberapa tinggi tingkat pemerolehan bahasa anak.
\end{abstract}

Kata Kunci: Pemerolehan Bahasa, Mean Length of Utterance, Fonologi, Morfologi, Sintaksis.

\begin{abstract}
The study, entitled "Analysis of Language Acquisition in Children aged 2.8 Years Based on the Mean Length of Utterance in Phonological Aspects of Morphology and Syntax" aims to describe the average speech length of children at the age of 2 years and 8 months, and to find out whether there are problems in the language acquisition process at the age of 2 years and 8 months toward children who become research subjects. The method used is descriptive analysis method with a qualitative approach. The results of this study can be seen that based on MLU calculations, the language ability of a child named Septi Asrilia Rahayu was quite high, far above the level it should be. Likewise, the phonological, morphological, and syntactic aspects can be said to be very good. And by doing this research, it can be seen that MLU was the right measurement method to find out how high the level of children's language acquisition was.
\end{abstract}

Keywords: Language Acquisition, Mean Length of Utterance, Phonology, Morphology, Syntax.

Copyright (c) 2021 Hana Septiana Jamal, Hendra Setiawan

$\triangle$ Corresponding author:

Email : 1710631080071@student.unsika.ac.id

DOI : https://doi.org/10.31004/edukatif.v3i6.1249

ISSN 2656-8063 (Media Cetak)

ISSN 2656-8071 (Media Online)

Edukatif : Jurnal Ilmu Pendidikan Vol 3 No 6 Tahun 2021 p-ISSN 2656-8063 e-ISSN 2656-8071 
3817 Analisis Pemerolehan Bahasa pada Anak Usia 2,8 Tahun berdasarkan Mean Length of Utterance dalam Aspek Fonologi Morfologi dan Sintaksis - Hana Septiana Jamal, Hendra Setiawan

DOI: https://doi.org/10.31004/edukatif.v3i6.1013

\section{PENDAHULUAN}

Menurut Putri dan Harahap (2021: 1) 'bahasa dapat mengontrol perilaku, merealisasikan tindakan, dan mengubah situasi'. Dapat disimpulkan bahwasanya seseorang dengan bahasa dapat melakukan hal-hal pula dapat ditafsir bagaimana seseorang tersebut. Dikuatkan oleh pandangan Syafroni (2016: 67) 'bahasa memiliki peran penting dalam kehidupan manusia. Selain sebagai media untuk melakukan tindakan, bahasa juga berfungsi sebagai cerminan budaya penuturnya. Bahasa dapat mengontrol perilaku, merealisasikan tindakan, dan mengubah situasi'. Dalam setiap kehidupan manusia tentunya tidak lepas dari bahasa, baik bahasa lisan, tulisan, maupun bahasa isyarat, dan setiap bentuk ujaran bahasa yang didapatkan oleh manusia tersebut tentunya memiliki proses yang tidak sama. Pemerolehan bahasa yang dialami oleh masing-masing manusia berbeda-beda, tergantung bagaiman lingkungan yang mereka tempati, kondisi, atau seperti apa peran orang tua dalam mengajarkan anaknya dalam berkomunikasi atau berbahasa. Dengan bahasa akan memudahkan anak mengekspresikan gagasan, kemuauannnya dengan cara yang benar-benar dapat diterima secara sosial.

Penelitian ini didasarkan pada teori psikolinguistik. Menurut (Triadi, 2017: 5) psikolinguistik adalah sebuah ilmu gabungan antara ilmu linguistik dengan ilmu psikologi. Kedua ilmu ini bergabung untuk memecahkan berbagai masalah yang timbul di kehidupan. Masalah tersebut antara lain tentang peroses pemerolehan bahasa pada anak, proses stimulus dan respon bahasa pada manusia, prilaku berbahasa kaitannya dengan psikologi manusia dan masih banyak permasalahan yang bisa diselesaikan oleh cabang ilmu ini. Penelitian dengan teori akan melihat bagaimana hasil pemerolehan pada anak dan menganalisis jika terjadi kekurangan atau kelebihan pemerolehan bahasa pada anak.

Pemerolehan bahasa merupakan sebuah hal yang sangat menakjubkan terlebih dalam proses pemerolehan bahasa pertama yang dimiliki langsung oleh anak tanpa ada pembelajaran khusus mengenai bahasa tersebut kepada anak. Bahasa memiliki peranan penting dalam kehidupan manusia, dan bahasa sebagai alat komunikasi. Selain sebagai media untuk melakukan tindakan, bahasa juga dapat berfungsi sebagai cerminan budaya penuturnya. Dalam proses perkembangan, semua anak manusia yang normal paling sedikit memeroleh satu bahasa alamiah. Dengan kata lain bahasa asli, awal (bahasa ibu) dalam tahun-tahun pertama kehidupannya. Dijelaskan menurut Dardjowidjojo (Qalbi, 2020: 51) pemerolehan (acquisition) merupakan sebuah istilah yang digunakan untuk mengkaji proses penguasaan bahasa yang dilakukan oleh anak waktu belajar bahasa ibu (native language).

Dalam pemerolehan bahasa ada dua faktor penting, yaitu faktor nurture dan faktor nature. Faktor nurture merupakan bahasa yang didapatkan oleh manusia berdasarkan lingkungan yang mereka tempati. Sedangkan, faktor nature adalah bahasa yang didapatkan sejak sesorang baru lahir. Kedua faktor ini sering kali didebatkan dengan pertanyaan apakah pemerolehan bahasa yang didapatkan oleh sesorang bersifat nurture atau nature. Seperti halnya aliran behaviorisme yang mengatakan pemerolehan bahasa itu bersifat nurture, yakni pemerolehan itu ditentukan oleh lingkungan. Lingkungan tempat tinggal merupakan salah satu faktor yang sangat penting bagi seseorang memperoleh bahasa. Orang yang lahir dan telah lama tinggal di daerah Jawa Barat kemungkin besar akan lebih sering berbicara menggunakan bahasa Sunda, atau bagi orangorang yang lahir dan telah lama tinggal di daerah Sumatera Barat kemungkinan besar akan lebih sering berbicara menggunakan bahasa Minang, sehingga hal tersebut menjadi tabiat karena lingkungan, maka akan terbawa dalam kehidupannya tanpa disadari. Begitu juga pendatang baru yang menetap di Jawa Barat, secara perlahan kosa kata bahasa Sundanya akan meningkat. Meskipun mulai bisa bahasa Sunda, mereka masih tetap sering menggunakan bahasa Ibu atau bahasa kedua ketika berkomunikasi.

Menurut Brookes (Supriatna, 2017: 35) bahwasanya pemerolehan bahasa dalam bentuk yang paling sederhana bagi bayi itu berumur 18 bulan dan akan mencapai bentuk yang hampir sempurna ketika berusia 4 tahun lebih ataupun kurang. Mereka akan mencapai hasil yang sempurna. Dengan itu, bagaimanakah pemerolehan bahasa ideal yang dialami oleh anak yang baru berusia 2 tahun lebih 8 bulan (32 bulan)? 
3818 Analisis Pemerolehan Bahasa pada Anak Usia 2,8 Tahun berdasarkan Mean Length of Utterance dalam Aspek Fonologi Morfologi dan Sintaksis - Hana Septiana Jamal, Hendra Setiawan

DOI: https://doi.org/10.31004/edukatif.v3i6.1013

Pemerolehan bahasa pada anak usia 2 tahun 8 bulan merupakan proses yang bersifat fisik dan psikis. Secara fisik, kemampuan anak dalam memproduksi kata-kata ditandai oleh perkembangan bibir, lidah, dan gigi mereka yang tengah tumbuh. Sedangkan secara psikis, kemampuan memproduksi kata-kata dan variasi ucapan sangat ditentukan oleh situasi emosional anak saat berlatih mengucapkan kata-kata. Namun, tentu saja tidak semua bayi berumur 2 tahun 8 bulan memililiki kemampuan pemerolehan bahasa yang ideal berdasarkan fisik dan psikis tersebut.

Kemampuan memperoleh bahasa yang dimiliki oleh anak berumur 2 tahun 8 bulan sangat dipengaruhi oleh beberapa faktor, seperti faktor orang-orang terdekatnya, terutama orang tua, kakek, nenek, kakak, atau keluarga lainnya, dan faktor kognitif anak. Orang tua yang sering mengajak anak usia tersebut berceloteh dan mengajarkan mereka mengucapkan bunyi-bunyi sederhana atau susunan kata yang singkat akan membuat sang anak terbiasa dalam mengucapkan bunyi-bunyi bahasa yang didengarnya. Dengan dilakukannya hal ini pemerolehan bahasa berdasarkan sifat fisik dan psikis anak usia 2 tahun 8 bulan akan berkembang dengan baik. Selain faktor yang diajarkan oleh orang tuanya, kemampuan pemerolehan bahasa anak usia 2 tahun lebih 8 bulan ditentukan juga oleh tingkat kognitifnya. Jika kemampuan kognitif anak pada usia tersebut baik, maka kemampuan berbahasa yang dimilikinya akan sesuai dengan tingkatan usianya atau bahkan bisa lebih tinggi.

Pemerolehan bahasa yang biasa didapatkan anak usia lima tahun kebawah adalah bahasa Ibu. Anak yang memiliki kemampuan fisik dan psikis normal akan mudah menggunakan bahasa Ibu sebagai alat komunikasi di lingkungan sekitarnya, walaupun tanpa adanya pembelajaran formal. Seperti yang telah diketahui, pemerolehan bahasa didapatkan langsung oleh seseorang tanpa harus mengikuti program Pendidikan formal. Kapan pun dan di mana pun seseorang bisa memperoleh bahasa, sehingga pemerolehan bahasa yang didapatkan oleh masing-masing orang sangat beragam. Oleh karena itu, pengkajian tentang pemerolehan bahasa harus dilakukan, terutama dalam bidang pebelajaran bahasa. Pengetahuan yang cukup dan hakikat pemerolehan bahasa yang semakin berkembang akan membuat tingkat keberhasilan bidang pengajaran bahasa semakin maju.

Brown (Marsis \& Annisa, 2018: 37) menyatakan pendekatan behavioristik berpendapat bahwa perilaku bahasa merupakan wujud dari tanggapan yang tepat terhadap stimuli. Jika respons terhadap tanggapan berulang-ulang, hal tersebut akan menjadi kebiasaaan. Dapat disimpulkan bahwa pemerolehan bahasa didapatkan dari kebiasaan menyimak dan melakukan respons. Mengenai bahasa ibu menurut Nababan (Nasution, 2019: 113) setiap anak yang normal akan belajar bahasa pertama (bahasa ibu) dalam tahun-tahun pertamanya dan proses itu terjadi hingga kira-kira umur lima tahun. Dapat disimpulkan bahwa anak akan belajar bahasa ibu sebagai bahasa pertamanya dari tahun pertama hingga umur lima tahun.

Penelitian ini dilandaskan pada banyak anak di bawah usia lima tahun kurang dalam pemerolehan bahasa dan memproduksinya dalam tuturan secara fonologis di mana anak masih banyak yang mengujarkan kata dengan cadel, artikulasi tidak jelas, dan sulit untuk memaknai atau menangkap maksud yang disampaikan oleh seorang anak. Oleh sebab itu, perlunya sebuah penelitian mendalam dan masif mengenai bagaimana proses pemerolehan bahasa anak dan bagaimana anak memproduksi bahasa dengan sederhana dan jelas. Di dunia ini bahasa sangatlah banyak dan beragam. Indonesia saja memiliki bahasa daerah sebanyak 652 bahasa daerah. Dengan itu bahwasanya merupakan suatu hal yang menakjubkan dan mestinya ada sebuah penelitian yang lebih lanjut, mendalam, dan terus tetap dilaksankan, terlebih mengenai bahasa yang diperoleh dan diproduksi oleh anak. Pendapat di atas sejalan dengan pandangan Supriatna (2017: 35) dalam penelitiannya yang berjudul Menemukan Pemerolehan Bahasa Kelas Kata Verba, Nomina, dan Adjektiva Pada Anak Usia 3 Tahun 10 Hari (Studi Kasus terhadap Pemerolehan Bahasa Anak Melalui Kajian Mean Length Utterance (MLU) Usia Dini) 'mengemukan bahwa pemerolehan bahasa pada anak usia dini merupakan suatu hal yang perlu ditelaah lebih mendalam bagaimana mereka menghasilkan bahasa yang sederhana dan jelas. Kita ketahui bahasa diperoleh oleh manusia sangat mengagumkan dan menarik untuk diteliti. Banyak teori baik yang 
3819 Analisis Pemerolehan Bahasa pada Anak Usia 2,8 Tahun berdasarkan Mean Length of Utterance dalam Aspek Fonologi Morfologi dan Sintaksis - Hana Septiana Jamal, Hendra Setiawan

DOI: https://doi.org/10.31004/edukatif.v3i6.1013

berkaitan dengan ilmu pengetahuan maupun hasil penelitian para ahli untuk menjelaskan bagaimana proses bahasa itu dihasilkan oleh anak usia dini. Disadari maupun tidak, sistem linguistik dikuasai dengan baik oleh individu kanak-kanak; meskipun tidak dalam pembelajaran formal.

Perbedaan penelitian dengan penelitian sebelumnya di mana pada penelitian ini menggunakan narasumber yang memakai bahasa ibunya, atau bahasa sunda dalam kesehariannya. Akan tetapi, narasumber juga mampu menggunakan bahasa keduanya atau bahasa Indonesia karena pengaruh atau faktor lingkungan. Penelitian ini mengkaji tiga aspek linguistik mikro yakni aspek fonologi, morfologi, dan sintaksis. Penelitian ini dilakukan guna melihat bagaimana pemerolehan bahas anak pada usianya yang masih 2 tahun 8 bulan dengan bagaimana pemerolehan bahasa secara fonologi yang berarti pengujarannya apakah masih cadel atau sudah sesuai dan dapat dimengerti dan jelas dalam bahasa ibu yang tertransliterasi ke dalam bahasa Indonesia. Dalam usia lima tahun ke bawah, umumnya anak-anak akan menguasai sistem fonologi, morfologi, dan sintaksis dalam bahasa pertamanya (bahasa Ibu). Pengembangan dan penguasan pemerolehan bahasa yang yang ada pada ketiga sistem tersebut akan dialami oleh anak-anak dengan proses yang bertahap. Untuk mengukur seberapa tinggi pemerolehan bahasa dalam bidang fonologi, morfologi, dan sintaksis ini dapat menggunakan pengukuran MLU (Mean Length of Utterance). Penelitian-penelitian yang telah dilakukan mengenai topik ini hanya membahas satu aspek saja seperti hanya aspek fonologinya saja, atau morfologinya saja, atau sintaksisnya saja. Penelitian ini mengkaji tiga aspek sekaligus dan hasil tuturan narasumber dihitung dengan pengkuran MLU.

MLU sendiri merupakan sutau konsep yang digunakan oleh para peneliti untuk mengukur seberapa tinggi produk linguistik yang dihasilkan oleh anak usia lima tahun ke bawah. Cara mengetahui hasil dari MLU dapat dilakukan dengan membagi jumlah bilangan morfom dengan bilangan ujaran. Minimal jumlah bilangan ujaran yang yang diperlukan ada 100 ujuran. Semakin tinggi hasil pengukuran MLU seorang anak, maka semakin tinggi pula penguasaan bahasa yang diperoleh anak tersebut. Penelitian dengan mengguanakan metode pengukuran MLU ini, bertujuan untuk mendeskripsikan rerata panjang tuturan anak pada usia 2 tahun 8 bulan, dan mengetahui apakah ada permasalahan dalam proses pemerolehan bahasa pada anak yang menjadi subjek penelitian. Dalam proses perkembangannya, semua anak normal paling sedikit memperoleh satu bahasa ilmiah. Dengan kata lain, setiap anak yang normal maka akan mengalami pertumbuhan yang wajar dalam memperoleh bahasa.

Dalam masalah kaitan antara konsep universal dengan pemerolehan fonologi, ahli yang sampai kini pandangannya belum disanggah adalah Roman Jakobson. Menurut Dardjowidjojo (dalam Yanti, 2016: 134) 'pemerolehan bahasa pada anak sejalan dengan konsep universal pemerolehan fonologi. Pemerolehan bunyi berjalan selaras dengan kodrat nunyi itu sendiri dan diperoleh anak melalui suatu cara yang konsisten. Bunyi pertama yang dikuasai anak adalah adalah kontras bunyi vokal dan konsonan. Dalam hal bunyi vokal terdapat tiga vokal utama yang muncul terlebih dahulu, yaitu [i], [u], dan [a]. Sistem kontras seperti itu disebut sistem vokal minimal (minimal vocal system) dan terdapat dalam semua bahasa. Artinya dalam bahasa mana pun ketiga bunyi vokal tersebut pasti ada. Dalam hal bunyi konsonan kontras pertama yang muncul adalah antara bunyi oral dengan bunyi nasal ([p-b], [m-n]) dan kemudian disusul oleh kontras antara bunyi bilabial dengan bunyi dental ([p], [t]). Sistem kontras seperti ini dinamakan sistem konsonantal minimal (minimal consonantal system). Lebih jauh Jacobson mengatakan bahwa hubungan antara bunyi yang satu dengan bunyi yang lain bersifat universal. Dengan demikian tampak bahwa pemerolehan bunyi-bunyi bahasa itu berlangsung secara berurutan. Vokal minimal akan diperoleh lebih awal daripada vokal-vokal lainnya; sedangkan konsonan hambat akan diperoleh lebih awal daripada konsonan frikatif, dan konsonan frikatif akan diperoleh lebih awal daripada afrikatif. Anak tidak mungkin dapat menguasai frikatif atau afrikat sebelum mereka menguasai konsonan hambat. Kontras antara bilabial [b] dengan dental [d] dikuasai lebih dahulu daripada antara bilabial [b] dengan velar $[\mathrm{g}]$ atau dental [d] dengan velar [g]. Kontras antara bilabial-dental [b-d] dikuasai sebelum frikatif [v-s]; bunyi hambat dan frikatif [b-d-v-s] dikuasai sebelum alveo-falatal [ts-də]. Hal itu sejalan dengan 
3820 Analisis Pemerolehan Bahasa pada Anak Usia 2,8 Tahun berdasarkan Mean Length of Utterance dalam Aspek Fonologi Morfologi dan Sintaksis - Hana Septiana Jamal, Hendra Setiawan

DOI: https://doi.org/10.31004/edukatif.v3i6.1013

apa yang disampaikan Ingram (1999) yang menyatakan bahwa konsonan pertama yang dikuasai anak adalah $[\mathrm{p}],[\mathrm{t}],[\mathrm{m}],[\mathrm{n}] '$.

Disimpulkan dari paparan di atas bahwasanya anak memeroleh bunyi secara sistematis dari bunyi yang mudah ke bunyi yang sukar. Seorang anak tidaklah mungkin memeroleh bunyi dari bunyi yang sukar ke bunyi yang mudah. Diperkuat oleh pandangan (Gani \& Arsyad, 2019) bahwa fonologi adalah cabang ilmu bahasa (linguistik) yang mengkaji bunyi-bunyi bahasa, proses terbentuknya dan perubahannya.

Dalam kajian linguistik atau ilmu kebahasaan, setelah melewati tahap fonologi akan menemui morfologi. Menurut Chaer (dalam Thabroni, 2020) 'morfologi adalah ilmu mengenai bentuk-bentuk dan pembentukan kata'. Diperjelas oleh Kridalaksana (Wibowo, 2016: 3) yang mengemukakan bahwa morfologi, yaitu (1) bidang linguistik yang memelajari morfem dan kombinasi-kombinasinya; (2) bagian sari struktur bahasa yang mencakup kata dan bagian-bagian kata, yaitu morfem. Menurut Chaer (Anam \& Awalludin, 2018) "Proses morfologis pada dasarnya adalah proses pembentukan kata dari sebuah bentuk dasar melalui pembubuhan afiks (dalam proses afiksasi), pengulangan (dalam proses reduplikasi), penggabungan (dalam proses komposisi), pemendekan (dalam proses akronimisasi), dan pengubahan status (dalam proses konversi)". Tetapi, tidak jarang anak-anak tersebut sering melakukan kesalahan dalam menuturkan kata-kata tertentu. Kesalahan menuturkan suatu kata maupun kalimat yang dilakukan oleh anak-anak dapat menyebabkan timbulnya kesalahan dalam memaknai tuturan tersebut. Ditambahkan menurut Verhaar (Siregar, 2020: 5) bahwa morfologi adalah bidang linguistik yang mempelajari susunan bagian kata secara gramatikal. Dijelaskan oleh Chaer (Islami, 2017: 3) mengungkapkan proses morfologis adalah proses pembentukan kata dari sebuah bentuk dasar melalui pembubuhan afiks (dalam proses afiksasi), pengulangan kata (dalam proses reduplikasi), penggabungan kata (dalam proses komposisi).

Adapun mengenai perkembangan Sintaksis menurut Ramlan (Qalbi, 2020: 53) sintaksis merupakan sebuah perkembangan seorang anak dimana ia sudah mulai mampu untuk menyusun kata, frasa, klausa dan kalimat yang bertujuan untuk berkomunikasi dengan orang lain. Kalimat-kalimat yang dihasilkan oleh anak tersebut diucapkan untuk memberikan informasi baru kepada pendengar. Kalimat awal pada anak adalah kalimat yang sederhana dan berorientasi berita kemudian meningkat menjadi kalimat tanya dan ingkar. Ditinjau dari segi bentuknya kalimat dapat dibedakan menjadi kalimat tunggal dan majemuk. Berdasarkan fungsinya dalam hubungan situasi, kalimat dapat digolongkan menjadi tiga golongan, yaitu kalimat berita, kalimat tanya, dan kalimat suruh. Dijelaskan oleh Ba'dulu \& Herman (Susanti, dkk, 2018: 891) sintaksis adalah telaah yang berkaitan dengan hubungan kata-kata atau satuan-satuan kata yang cakupannya lebih besat dalam sebuah kalimat. Dengan kata lain, sintaksis adalah telaah tentang struktur kalimat.

Setiap anak mengalami perkembangan bahasa yang berbeda-beda. Namun pada setiap anak yang normal mulai berbicara antara umur 20 bulan sampai 28 bulan. Hal tersebut terjadi karena organ-organ bicara yang dimiliki setiap anak sudah mulai berkembang dan terprogram untuk memperoleh bahasa. Salah satu bidang pemerolehan bahasa pada anak menyangkut bidang semantik. Bidang semantik meliputi kemampuan anak dalam memahami ujaran mitra tuturnya, seperti kemampuan memahami kata yang diucapkan oleh mitra tuturnya. Salah satu golongan kosakata yang dikuasai oleh anak adalah golongan kelas kata nomina terutama yang akrab dengan tempat tinggalnya. (Manik, dkk, 2020: 114)

MLU merupakan pengukur untuk perkembangan sintaksis anak. Menurut Brown (Dardjowidjoyo ) (Supriatna, 2017: 43) cara memghitung MLU dapat dilakukan dengan beberapa langkah. Pertama, mengambil sampel sebanyak 100 ujaran. Kedua, menghitung jumlah morfemnya. Ketiga, membagi jumlah morfem dengan jumlah ujaran, seperti pada rumus berikut.

MLU $=\underline{\text { Jumlah Morfem }}$

Jumlah Tuturan

Brown (dalam Supriatna, 2017: 43) membagi tahap pemerolehan bahasa anak berdasarkan MLU menjadi sepuluh tahap, yakni: 
3821 Analisis Pemerolehan Bahasa pada Anak Usia 2,8 Tahun berdasarkan Mean Length of Utterance dalam Aspek Fonologi Morfologi dan Sintaksis - Hana Septiana Jamal, Hendra Setiawan DOI: https://doi.org/10.31004/edukatif.v3i6.1013

Tabel 1

Tahap MLU

\begin{tabular}{rlll}
\hline No & Periode & MLU & Usia \\
\hline 1. & Tahap I & $1-1,5$ & $12-22$ bulan \\
\hline 2. & Tahap II & $1,5-2,0$ & $27-28$ bulan \\
\hline 3. & Tahap III & $2,0-2,25$ & $27-28$ bulan \\
\hline 4. & Tahap IV & $2,25-2,5$ & $28-30$ bulan \\
\hline 5. & Tahap V & $2,5-2,75$ & $31-32$ bulan \\
\hline 6. & Tahap VI & $2,75-3,0$ & $33-34$ bulan \\
\hline 7. & Tahap VII & $3,0-3,5$ & $35-39$ bulan \\
\hline 8. & Tahap VIII & $3,5-3,45$ & $38-40$ bulan \\
\hline 9. & Tahap IX & $3,5-3,45$ & $41-47$ bulan \\
\hline 10. & Tahap X & $45+$ & 47 bulan \\
\hline
\end{tabular}

\section{METODE PENELITIAN}

Menurut Sugiyono (2017: 9) metode penelitian kualitatif adalah metode penelitian yang berlandaskan pada filsafat postpositivisme digunakan atau interpretif, digunakan untuk meneliti pada kondisi objek yang alamiah. Dikuatkan juga oleh Dalam hal ini, peneliti adalah sebagai instrumen kunci, teknik pengumpulan data dilakukan secara triangulasi, data yang diperoleh cenderung data kualitatif, analisis data bersifat induktif/ kualitatif, dan hasil penelitian bersifat untuk memahami makna, memahami keunikan, mengkontruksi fenomena, dan menemukan hipotesis. Tujuan pokok dalam penelitian kualitatif adalah menggambarkan, mempelajari, dan menjelaskan fenomena itu. Pemahamannya dapat diperoleh dengan cara mendeskripsikan dan mengeksplorasikan dalam sebuah narasi'. Dijelaskan menurut Ra Ditambahkan menurut Ratna (2015: 44) 'metode kualitatif memberikan perhatian terhadap data alamiah, data dalam hubungannya dengan konteks keberadaannya. Cara-cara inilah yang mendorong metode kualitatif dianggap sebagai multimetode sebab penelitian pada gilirannya melibatkan sejumlah besar gejala sosial yang relevan. Dalam penelitian karya sastra, misalnya, akan dilibatkan pengarang, lingkungan sosial di mana pengarang berada, termasuk unsur-unsur kebudayaan pada umumnya'.

Penelitian ini menggunakan metode analisis deskriptif dengan pendekatan kualitatuif. Menurut Arikunto (Hayati, 2020) pengertian subjek penelitian adalah sebagai tempat di mana data diperoleh dan ditentukan dalam kerangka pemikiran. Subjek dalam penelitian ini adalah seorang anak berusia 2,8 tahun. Objeknya adalah data atau instrumen dalam penelitian ini adalah data MLU anak perempuan berusia 2 tahun 8 bulan (32 bulan). Penelitian ini hanya menggunakan satu sampel anak sebagai analisis MLU yaitu Septi Asrilia Rahayu Yudiana (Ayu) dengan usia 2 tahun 8 bulan (32 bulan). Dia seorang anak pedagang ikan di Waduk Jatiluhur Purwakarta dan tinggal di desa Galumpit kecamatan Tegalwaru kabupaten Purwakarta. Saat penelitian ia tengah di berlebaran di rumah kakeknya di Legonkulon, Subang.

a. Data diri responden

Nama

Tempat, tanggal lahir

Alamat
: Septi Asrilia Rahayu Yudiana

: Purwakarta, 20 September 2017

: Ds. Galumpit Kec. Tegalwaru Kab. Purwakarta

b. Data diri orangtua responden

Nama Ayah

Tempat, tanggal lahir

Nama Ibu

Tempat, tanggal lahir Alamat
: Yudiana Yudistira, S.Kom.

: Purwakarta, 10 Desember 1988

: Hani Yulianingsih, S.Pd..

: Subang, 09 Juli 1990

: Ds. Galumpit Kec. Tegalwaru Kab. Purwakarta 
Penelitian ini menggunakan bahan dari rekaman suara anak yang diteliti (Septi Asrilia Rahayu Yudiana (Ayu)). Teknik pengumpulan data menggunakan ajakan mengobrol dan bermain bersama, kemudian direkam melalui rekaman suara dan rekaman video. Jenis kata yang yang telah dikenal subjek penelitian adalah nomina $(\mathrm{N})$, verba (V), adjektiva (Adj), adverbia (Adv), numeralia (Num), partikel (P), dan pronomina (Pron). Bila dilihat dari pola kalimat, Septi Asrilia Rahayu Yudiana telah mampu bertutur dengan pola dengan pola dasar, seperti FN + FV, FN + FN, FN + FAdj, FV + FAdj, dan FV + Adv. Data yang diteliti berjumlah 100 data yang direkam selama lebih kurang enam hari. Dimulai dari perkembangan tuturan 1 kata hingga tuturan 7 kata. Analisis dilakukan dengan beberapa langkah, pertama pentranskripsian data. Di mana tuturan narasumber dengan perekaman melalui alat rekaman dan gawai, kemudian ditranskripsikan dalam bentuk kalimat. Data kemudian disusun dalam bentuk struktur kalimat bahasa atau tuturan kanak-kanak. Kedua, penyeleksian data. Di mana data yang telah ditranskripsi diolah dengan mengambil data-data yang akan diteliti dengan memenuhi syarat yang sesuai dengan tujuan penelitian. Data tersebut adalah tuturan yang memenuhi syarat untuk dihitung $M L U$-nya. Ketiga, pentransliterasian bahasa dari bahasa daerah (sunda) ke bahasa Indonsia yang baku. Data yang sudah diseleksi kemudian ditransliterasi. Keempat, pengklasifikasian data. Di mana data yang telah diseleksi, dan ditransliterasi, dapat sesuai dengan tujuan penelitian dan dapat dihitung $M L U$-nya. Caranya dengan mengklaksifikasi data dengan. Dan kelima, pemaparan hasil analisis data.

\section{HASIL DAN PEMBAHASAN PENELITIAN}

\section{Hasil Transkripsi Ujaran dan Jumlah Morfem serta Analisis Sintaksis}

Hasil rekaman tuturan anak yang telah ditranskripsikan dan ditransliterasikan, kemudian dianalisis jumlah morfemnya serta dianalisis sintaksisnya. Hasil rekaman tuturan narasumber yang telah ditranskripsi ejaan fonetik yang diartikan ke dalam bahasa Indonesi yang sebelumnya telah melewati tahap transliterasi. Data yang diteliti berjumlah 100 ujaran. Penjelasannya sebagai berikut:

Transkrip Data 100 Ujaran Subjek Penelitian

a. Ujaran-ujaran 1 kata:

1. Nenek

2. Satu

3. Minum

4. Asalamualaikum

5. Mama

6. Nanti

7. Setan

8. Mau

9. Takut

10. Panjang

11. Galak

12. Kemarin

13. Iya

14. Cantik

b. Ujaran-ujaran 2 kata:

1. Lagi ini

2. Satu sudah

3. Bukan Ayu

4. Mama ayu 
3823 Analisis Pemerolehan Bahasa pada Anak Usia 2,8 Tahun berdasarkan Mean Length of Utterance dalam Aspek Fonologi Morfologi dan Sintaksis - Hana Septiana Jamal, Hendra Setiawan DOI: https://doi.org/10.31004/edukatif.v3i6.1013
5. Tidak ah
6. Jajan dadah
7. Lagi apa
8. Kakek mau
9. Nih sudah
10. Mama tidur
11. Di sini
12. Ih Mama
13. Sama adik
14. Sudah dong
15. Mau lagi
16. Biar deh
17. Tidak ah
18. Mau tidak
19. Enak lagi
20. Baju aku

21. Main motor

22. Begini-begini

23. Ke pantai

24. Nenek ikut

c. Ujaran-ujaran 3 kata:

1. Menutup ini

2. Naik dengan cuman

3. Bakar-bakar ya

4. Mau ke kakek

5. Nih enak ya

6. Susu aku habis

7. Nenek ayo Nenek

8. Ambil lagi gih

9. Kakek bisa apa

10. Kakek apa Lana

11. Jangan punya Ayu

12. Sama Mama Ayu

13. Sama Mama muda

14. Nanti diajak

15. Ramai tadi mah

16. Pipis adik Nenek

17. Ke Bandung Surabaya

d. Ujaran-ujaran 4 kata:

1. Dua tiga empat lima

2. Jangan duduk bangun Nenek

3. Tiga tiga ditarik

4. Sudah lari yang cepat 
3824 Analisis Pemerolehan Bahasa pada Anak Usia 2,8 Tahun berdasarkan Mean Length of Utterance dalam Aspek Fonologi Morfologi dan Sintaksis - Hana Septiana Jamal, Hendra Setiawan

DOI: https://doi.org/10.31004/edukatif.v3i6.1013

5. Aku mah mau pulang

6. Lagi airnya Kek

7. Sudah sudah sama Ayu

8. Dimakan sama Ayu

9. Tidak apa apa deh

10. Mobil-mobilan ah

11. Huh jangan ke sini

12. Ayah mah main motor

13. Nenek ada apanya

14. Nenek mau ditiup

15. Ayo dong usik aku

16. Jambunya sudah habis

17. Ada Nenek ada Kakek

18. Ih ada setan takut

19. Merah-merah euhm enak

e. Tuturan-tuturan 5 kata:

1. Gendong ini nih tuh itu

2. Ah habiskan susunya

3. Tidak ih tidak akan tumpah

4. Tuh si Hana mah jatuh

5. Itunya ada saja ya

6. Ayu mah punya permen ini

7. Supperzupper dapat dari Kak Eva

8. Tuh aku mah punya ini

9. Tuh Ayu mah bisa begini

10. Ayu mah seperti laki-laki

11. Jelek-jelek Om Gendut Jelek

12. Kok tidak ada tanah ya

13. Panjang rambut Mama muda mah

14. Dua dua aku sayang Ayah

f. Ujaran-ujaran 6 kata:

1. Nih satu satu aku sayang Ayah

2. Mau ke sawah awas Om Gendut

3. Tidak nenek Mama susunya mana

4. Mama airnya kurang minum segelas

5. Ini kasih handuk jadinya habis

6. Sudah habis lagi susunya ah

7. Mau dicelana mau keluar

g. Ujaran-ujaran 7 kata:

1. Ah mau lagi susunya mau lagi

2. Memasukkan susunya sama adik

3. Mama tadi kemanakan punya adik 
3825 Analisis Pemerolehan Bahasa pada Anak Usia 2,8 Tahun berdasarkan Mean Length of Utterance dalam Aspek Fonologi Morfologi dan Sintaksis - Hana Septiana Jamal, Hendra Setiawan

DOI: https://doi.org/10.31004/edukatif.v3i6.1013

4. Tinggal beli lagi aku mah susunya

5. Ada si Lana Mama Lana Om Gendut

Tabel 2

Perhitungan pembahasan $M L U$ subjek penelitian

\begin{tabular}{lcc}
\hline \multicolumn{1}{c}{ Jumlah Kata Per Tuturan } & $\begin{array}{c}\text { Jumlah } \\
\text { Tuturan }\end{array}$ & $\begin{array}{c}\text { Jumlah } \\
\text { Morfem }\end{array}$ \\
\hline Kalimat satu kata & 14 & 14 \\
\hline Kalimat dua kata & 24 & 48 \\
\hline Kalimat tiga kata & 17 & 54 \\
\hline Kalimat empat kata & 19 & 72 \\
\hline Kalimat lima kata & 14 & 70 \\
\hline Kalimat enam kata & 7 & 42 \\
\hline Kalimat tujuh kata & 5 & 35 \\
\hline Total & 100 & 335 \\
\hline
\end{tabular}

$M L U=\frac{\text { Jumlah Morfem }}{\text { Jumlah tuturan }}=\frac{335}{100}=3.35$

Berdasarkan hasil pengukuran $M L U$ di atas, panjang tuturan Septi Asrilia Rahayu Yudiana adalah 3.35 kata per tuturan. Bila disesuaikan dengan Brown, $M L U$ Septi Asrilia Rahayu Yudiana ada perbedaan sedikit, yaitu jika dilihat dari hasil angka $M L U$ yaitu 3.35 maka Septi Asrilia Rahayu Yudiana berada pada tahap VII antara 3,0-3,5 kata pertuturan. Dengan kata lain menurut teori Brown Owens yang menyatakan seharusny pada usia 32 bulan berada pada tahap V dengan interval 2,5-2,75. Maka, Septi Asrilia Rahayu Yudiana telah melebihi perhitungan tuturan menurut Brown Owens. Berdasarkan data yang diperoleh dan dikelompokkan, Septi Asrilia Rahayu Yudiana telah mampu bertutur dari kalimat satu kata sampai kalimat tujuh kata. Jenis kata yang sudah dikenal Septi Asrilia Rahayu Yudiana adalah nomina (N), numeralia (Num), adjektiva (Adj), adverbia (Adv), pronomina (Pron) dan partikel (P). Apabila dilihat dari pola kalimat, Septi Asrilia Rahayu Yudiana telah mampu bertutur dengan pola kalimat dengan pola dasar FN + FV, FN + FAdj, FN + FN, FV +FAdv + FV, FNum + FAdv, FAdv + FPron, FV + FPron, FP + FN, dan FV + FP. Ayu sudah mampu bertutur dengan pola kalimat yang menunjukkan kata benda, kata bilangan, kata sifat, kata keterangan, kata sifat, dan kata tugas. Hal itu menjelaskan bahwasanya Septi Asrilia Rahayu Yudiana (Ayu) telah memeroleh bahasa dan memproduksi bahasa dengan baik. Di mana tuturan Ayu di usianya yang baru 2 tahun 8 bulan sudah banyak memproduksi ujaran dengan kalimat lebih dari satu kata. Ayu pun, telah banyak memeroleh dan memproduksi bahasa secara aspek sintaksis di mana ia telah memeroleh banyak jenis kata, walaupun masih ada beberapa dalam kalimat yang tuturkan belum jelas struktur sintaksisnya.

Melihat hasil penelitian di atas bahwasanya narasumber anak yang baru berusia 2 tahun 8 bulan sudah mampu memproduksi bahasa dengan apa ia tuturkan dengan artikulasi yang jelas. Di mana narasumber bernama Septi Asrilia Rahayu Yudiana telah mampu mengujarkan tuturan seacara aspek fonologi tanpa cadel dan membuat mitra tutur kebingungan dalam memaknai apa yang ditutrkan penutur (anak). Pengujaran yang dituturkan Ayu sangatlah jelas artikulasinya. Selain itu Ayu pun sudah mengatahui jenis kalimat. Mana kalimat imperatif dan bagaimana mengujarkannya, mana kalimat interogatif dan bagaimana mengujarkannya, mana kalimat deklaratif dan bagaimana mengujarkannya, serta kalimat ekspresif dan bagaimana mengujarkannya.

Secara keseluruhan berdasarkan data di atas Septi Asrilia Rahayu Yudiana telah banyak berujar dengan fonetis yang jelas, menggunakan prefiks, sufiks dan konfiks. Seperti kata "diajak" yang memiliki morfem \{di\}sebagai prefiks dan morfem\{ajak\}sebagai kata dasar. Adapun sufiks terdapat pada kata "susunya", dengan morfem \{susu\} sebagai kata dasar dan \{nya\} sebagai sufiks. Adapun penggunaan 
3826 Analisis Pemerolehan Bahasa pada Anak Usia 2,8 Tahun berdasarkan Mean Length of Utterance dalam Aspek Fonologi Morfologi dan Sintaksis - Hana Septiana Jamal, Hendra Setiawan

DOI: https://doi.org/10.31004/edukatif.v3i6.1013

konfiks terdapat pada kata "memasukkan", dengan konfiks me-kan, dengan kata asal masuk. Tentu saja, dengan itu Septi Asrilia Rahayu Yudiana yang baru berusia 2 tahun 8 bulan (32 bulan) sudah mampu menggunakan afiksasi dengan benar sesuai kaidah morfologi.

Menurut Maryani (2018: 42) 'anak usia 3-5 tahun rata-rata dapat menggunakan 900-1000 kosa kata yang berbeda. Mereka menggunakan 3-5 kata dalam satu kalimat yang dapat berbentuk kalimat pernyataan, negatif, tanya, dan perintah. Anak usia 4 tahun sudah mulai menggunakan kalimat yang beralasan seperti "saya menangis karena sakit". Pada usia 5 tahun pembicaraan mereka mulai berkembang dimana kosa kata yang digunakan lebih banyak dan rumit'. Melihat dari pandangan tersebut Ayu sudah mampu memproduksi sampai tujuh kata dalam ujarannya.

\section{KESIMPULAN}

Simpulan yang dapat dibuat berdasarkan hasil data analisis terhadap Septi Asrilia Rahayu Yudiana yang berusia 2 tahun 8 bulan (32 bulan) di mana ia telah memeroleh indeks MLU (Mean Length of Utterance) dengan angka 3.35 kata per tuturan. Bila disesuaikan dengan Brown, MLU Septi Asrilia Rahayu Yudiana ada perbedaan sedikit, yaitu jika dilihat dari hasil angka $M L U$ yaitu 3.35 maka Septi Asrilia Rahayu Yudiana berada pada tahap VII antara 3,0-3,5 kata pertuturan. Dengan kata lain menurut teori BrownOwens yang menyatakan seharusnya pada usia 32 bulan berada pada tahap V dengan interval 2,52,75. Maka, Septi Asrilia Rahayu Yudiana telah melebihi perhitungan tuturan menurut Brown Owens. Berdasarkan data yang diperoleh dan dikelompokkan, Septi Asrilia Rahayu Yudiana telah mampu bertutur dari kalimat satu kata sampai kalimat tujuh kata. Jenis kata yang sudah dikenal Septi Asrilia Rahayu Yudiana adalah omina (N), numeralia (Num), adjektiva (Adj), adverbia (Adv), pronomina (Pron) dan partikel (P). Apabila dilihat dari pola kalimat, Septi Asrilia Rahayu Yudiana telah mampu bertutur dengan pola kalimat dengan pola dasar FN + FV, FN +FAdj, FN + FN, FV + FAdv + FV, FNum + FAdv, FAdv + FPron, FV + FPron, FP + FN, dan FV + FP. Ayu telah mampu bertutur dari kalimat satu kata hingga kalimat tujuh kata yang berarti Ayu telah mampu bertutur kalimat lengkap. Dengan kata lain Septi Asrilian Rahayu Yudiana (Ayu) pada dasarnya telah mampu menemukan pemerolehan bahasa kelas kata verba, nomina, dan adjektiva dengan baik. Secara aspek fonologi Ayu sudah dapat mengujarkan tuturan dengan artikulasi yang jelas, berujar dengan jenis kalimat yang sesuai. Ayu sudah mampu membedakan dan mengujarkan kalimat imperatif, interogatif, deklaratif, dan ekspresif dengan benar. Demikian dengan aspek morfologi Septi Asrilia Rahayu Yudiana telah banyak berujar dengan morfologis yang banyak, menggunakan prefiks, sufiks dan konfiks. Seperti kata "diajak" yang memiliki morfem \{di\}sebagai prefiks dan morfem \{ajak\}sebagai kata dasar. Adapun sufiks terdapat pada kata "susunya", dengan morfem \{susu sebagai kata dasar dan \{nya\} sebagai sufiks. Adapun penggunaan konfiks terdapat pada kata "memasukkan", dengan konfiks me- kan, dengan kata asal masuk. Tegasnya, Septi Asrilia Rahayu Yudiana yang baru berusia 2 tahun 8 bulan (32 bulan) sudah mampu menggunakan afiksasi dengan baik. Dari penelitian sederhana dan singkat ini perumusan tahap pemerolehan bahasa pertama (bahasa ibu) dikatakan cukup efektif untuk penghitungan $M L U$ pada anak-anak dan Septi Asrilia Rahayu Yudian telah mampu memeroleh bahasa pertama atau bahasa ibu dengan baik dan mampu memprouduksinya

\section{DAFTAR PUSTAKA}

Anam, S., \& Awalludin, A. (2018). Kajian Morfologis Tuturan Anak Usia 5 Tahun. Jurnal Bindo Sastra, 2(2), 240. https://doi.org/10.32502/jbs.v2i2.1264

Annisa, W. (2018). Pemerolehan Bahasa Anak Di Sumatera Barat (Kajian Mean Length of Utterance [Mlu]). Lingua, 14(1), 35-40.

Dardjowidjojo, S. (2010). Psikolinguistik: Pengantar Pemahaman Bahasa Manusia. Jakarta: Yayasan Obor. 
3827 Analisis Pemerolehan Bahasa pada Anak Usia 2,8 Tahun berdasarkan Mean Length of Utterance dalam Aspek Fonologi Morfologi dan Sintaksis - Hana Septiana Jamal, Hendra Setiawan DOI: https://doi.org/10.31004/edukatif.v3i6.1013

Gani, S., \& Arsyad, B. (2019). Kajian Teoritis Struktur Internal Bahasa (Fonologi, Morfologi, Sintaksis, dan Semantik). `A Jamiy: Jurnal Bahasa Dan Sastra Arab, 7(1), 1. https://doi.org/10.31314/ajamiy.7.1.120.2018

Kristiana Maryani. (2018). Pemerolehan Sintaksis Pada Anak Usia 3, 4, dan 5 Tahun. Jurnal Pendidikan Karakter "JAWARA" (JPKJ), 4, 41-47.

Manik, D., Oktavianda, R., \& Lubis, F. (n.d.). Pemerolehan Bahasa Anak ( Kajian Mean Length of Utterence ' $M L U$ ') Farzan Zefa Marpaung. 113-117.

Nafisah, S. (2017). Proses Fonologis Dan Pengkaidahannya. Deiksis, 09(01), 70-78. Retrieved from https://journal.lppmunindra.ac.id/index.php/Deiksis/article/download/940/1058

Nasution, R. S. (2019). Analisis pemerolehan sintaksis menggunakan teknik MLU (meant leght of utterence) pada anak usia 5 tahun. Bahastra, 3(2), 113-118. Retrieved from https://jurnal.uisu.ac.id/index.php/Bahastra/article/download/1149/913

Putri, R. A., \& Harahap, R. (n.d.). Pemerolehan Bahasa Anak Suku Karo Sumatera Utara ( Kajian Mean Length of Utterance [MLU ]).

Qalbi, S. U. (2020). Jenis Kalimat pada Tuturan Anak Usia Empat Tahun: Kajian Sintaksis. Jurnal Disastra, 2(1).

Rafiuddin, N. (2018). Proses Morfologis Reduplikasi Pada Buku Kumpulan Sajak Hujan Bulan Juni Karya Sapardi Djoko Damono Skripsi.

Ratna, Nyoman Kutha. 2015. Teori, Metode, dan Teknik Penelitian Sastra: dari Strukturalisme hingga Postukturalisme Persektif Wacana Naratif. Yogyakarta: Pustaka Pelajar.

Siregar, I. (2020). Iskandarsyah siregar 2020 1. 1-61.

Sugiyono. (2017). Metode Penelitian Kuantitatif, Kualitatif dan R\&D. Bandung: PT Alfabet.

Supriatna, E. (2017). Menemukan Pemerolehan Bahasa Kelas Kata Verba, Nomina, Dan Adjektiva Pada Anak Usia 3 Tahun 10 Hari (Studi Kasus terhadap Pemerolehan Bahasa Anak Melalui Kajian Mean Length Of Utterance (MLU) Usia Dini. Jurnal Semantik, 5(1), 34-54.

Susanti, S., Rahmasandy, A. A., \& ... (2018). Analisis Pemerolehan Bahasa Pada Anak Usia 1 Tahun 6 Bulan Dari Segi Sintaksis. Bahasa Dan Sastra , 1(November), 889-896. Retrieved from https://www.journal.ikipsiliwangi.ac.id/index.php/parole/article/view/1582

Syafroni, R. N. (2016). Panjang Rata-Rata Tuturan Anak Usia 2 Tahun 7 Bulan Dalam Bingkai Teori Pemerolehan Bahasa Anak. Jurnal Pendidikan Unsika, 4(1), 66-77.

Thabroni, G. (2020). Morfologi: Pengertian, Proses Morfologis, dan Morfofonemik.

Triadi, Rai Bagus. (2017). Studi Kasus Akuisisi Bahasa Pada Anak Usia (Kajian Psikolinguistik). Vol. 4, No. 1. Diperoleh pada 19 Agustus 2021, http://openjournal.unpam.ac.id/index.php/Sasindo/article/view/830

Wibowo, S. E. (2016). Morfologi (Sebuah Pengantar Ringkas). Purwodadi: CV. Sarnu Untung.

Yanti, P. G. (2016). Pemerolehan Bahasa Anak: Kajian Aaspek Fonologi Pada Anak Usia 2 - 2,5 Tahun. Jurnal VISI, 11(2), 131-141. 